\title{
Anilinolysis of Diphenyl Thiophosphinic Chloride and Theoretical Studies on Various $\mathrm{R}_{1} \mathbf{R}_{2} \mathrm{P}(\mathrm{O}$ or $\mathrm{S}) \mathrm{Cl}^{\dagger}$
}

\author{
Nilay Kumar Dey, In-Suk Han, and Hai Whang Lec

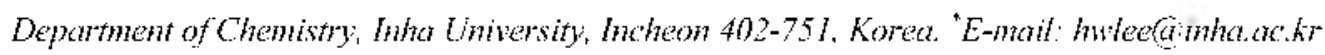 \\ Received October 4, 2007
}

\begin{abstract}
The aminolysis of diphenyl thiophosphinic chloride (2) with substituted anilines in acetonitrile at $55.0^{~ "} \mathrm{C}$ is investigated kinctically. Kinctic results yield large lammett $\rho_{\mathrm{X}}\left(\rho_{\mathrm{uuc}}=-3.97\right)$ and Brônsted $\beta_{\mathrm{X}}\left(\beta_{\mathrm{uxc}}=1.40\right)$ values. $\Lambda$ concerted mechanism involving a partial frontside nucleophilic attack through a hydrogen-bonded, four-center type transition state is proposed on the basis of the primary nomal kinetic isotope eflects $\left(k_{1} / k_{1}\right)=$ 1.0-1.1) with deuterated aniline $\left(\mathrm{XC}_{6} \mathrm{H}_{4} \mathrm{ND}_{2}\right)$ nucleophiles. The natural bond order charges on $\mathrm{P}$ and the degrees of distortion of 42 compounds: chlorophosphates $\left[\left(\mathrm{R}_{1} \mathrm{O}\right)\left(\mathrm{R}_{2} \mathrm{O}\right) \mathrm{P}(=\mathrm{O})(\mathrm{C}] \mathrm{l}\right.$, chlorothiophosphates $\left[\left\langle\mathrm{R}_{3} \mathrm{O}\right)\left(\mathrm{R}_{2} \mathrm{O}\right) \mathrm{P}(=\mathrm{S}) \mathrm{Cl}\right]$, phosphonochloridates $\left[\left(\mathrm{R}_{1} \mathrm{O}\right) \mathrm{R}_{2} \mathrm{P}(=\mathrm{O}) \mathrm{Cl}\right]$, phosphonochlorothioates $\left[\left(\mathrm{R}_{3} \mathrm{O}\right) \mathrm{R}_{2} \mathrm{P}(=\mathrm{S}) \mathrm{Cl}\right]$, chlorophosphinates $\left[\mathrm{R}_{1} \mathrm{R}_{2} \mathrm{P}(=\mathrm{O}) \mathrm{Cl}\right]$, and chlorothiophosphinates $\left[\mathrm{R}_{1} \mathrm{R}_{2} \mathrm{P}(=\mathrm{S}) \mathrm{Cl}\right]$ are calculated at the $\mathrm{B} 3 \mathrm{LYP} /$ $6-311$ । $(\mathrm{r}(\mathrm{d}, \mathrm{p})$ level in the gas phase.
\end{abstract}

Key Words : Anilinolysis of diphenyl thiophosphinic chloride, Frontside nucleophilic attack, Deuterium kinetic isotope eflect, NBO charge, I)egrec of distortion

\section{Introduction}

Phosphoryl transler is an insportant part of many biological chemistry and organic syntheses. ' Nucleophilic substitution reactions at phosphorus in tetracoordinate pentacovalent phosphorus esters and related compounds generally proced either stepwise with a trigonal bipyranidal pentacoordinate (TBP-5C) internediale or through an $\mathrm{S} \times 2$ mechanisn with a single transition state (TS). ${ }^{\text {b-t.2 }}$ When the atlacking and leaving groups occupy apical positions [ap $(\mathrm{Nu})-\mathrm{ap}(\mathrm{Lg})]$, i.e., backside nucleophilic altack, the conliguration is inverted, but when the nuclcophile attacks frontside toward the leaving group, the conliguration is retained. When backside and frontside nucleophilic attacks occur simultancously, the relative inportanee of the reaction pathways leads to products with inversion or retention of conliguration depending on the nucleophile, the leaving group, and the reaction conditions. "

In our preceding papers, and thiophosphoryl transfer reactions kinctically and theoretically. Partial frontside nucleophilic altack was suggested for reactions of aryl bis(4-methoxyphenyl) phosphates with less basic pyridines, ${ }^{4}$ aryl phenyl isothiocyanophosphates with more basic pyridines; ${ }^{\text {th }}$ aryl phenyl chlorothiophosphates with anilines, ${ }^{\text {ti }}$ diphenyl phosphinic chlorides with anilines; ${ }^{\text {ti }}$ diphenyl thiophosphinic chlorides with more basic pyridines; ${ }^{+1}$ and aryl thyl chloro and chlorothio phosphates with anilines.

In this work, we investigate the aminolysis of diphenyl thiophosphinic chloride (2) with substituted anilines and deuterated anilines $\left(\mathrm{XC}_{6} \mathrm{H}_{4} \mathrm{NII}_{2}\right.$ and $\left.\mathrm{XC}_{6}, \mathrm{I}_{4} \mathrm{NI}_{2}\right)$ in acetonitrile at $55.0^{\circ} \mathrm{C}$, ec. (1), to clarify the phesphoryl transfer mechanism, as well as to compare the reactivity of diphenyl

"This paper is dedicatiol to l'rolessor Sang (hul Shim on the occasion of his honorable retirement. phosphinic chloride (1), ${ }^{3 d}$ diphenyl chlorophosphate (3), ${ }^{3 \text { in }}$ and diphenyl chlorothiophosphate (4). ${ }^{3 *}$
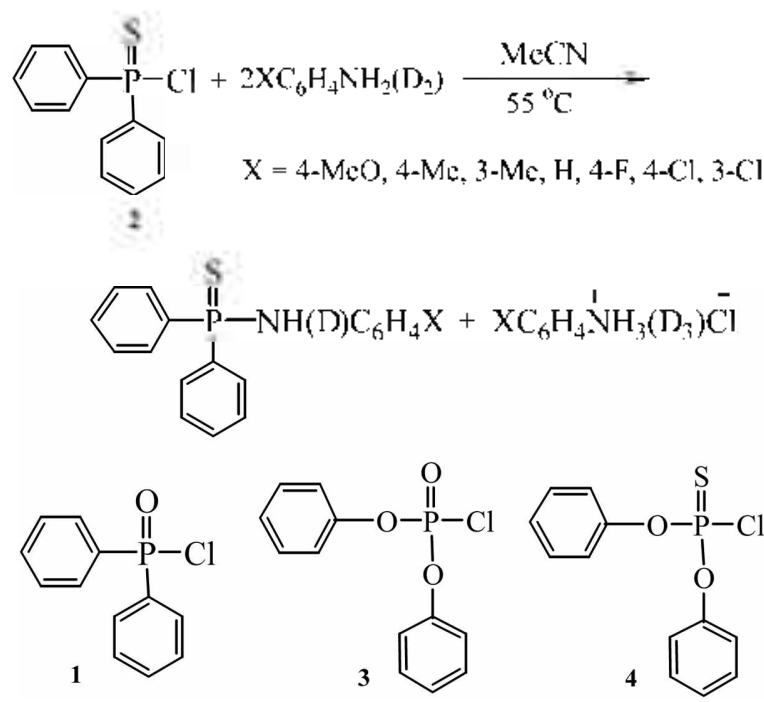

We also calculate the natural bond order (NBO) charge on $P$ and degree of distortion of various chlorophosphates $\left[\left\langle\mathrm{R}_{1} \mathrm{O}\right)\left(\mathrm{R}_{2} \mathrm{O}\right) \mathrm{P}(=\mathrm{O}) \mathrm{C}\right]$, chlorothiophosphates $\left[\left(\mathrm{R}_{1} \mathrm{O}\right)\left(\mathrm{R}_{2} \mathrm{O}\right)\right.$ $\mathrm{P}(=\mathrm{S}) \mathrm{Cl}$, phosphonochloridates $\left[\left(\mathrm{R}_{1} \mathrm{O}\right) \mathrm{R}_{2} \mathrm{P}(=\mathrm{O}) \mathrm{Cl}\right]$, phosphonochlorothioates $\left[\left(\mathrm{R}_{1} \mathrm{O}\right) \mathrm{R}_{2}[\mathrm{P}(=\mathrm{S}) \mathrm{C}]\right.$ ], chlorophosphinates $\left[\mathrm{R}_{1} \mathrm{R}_{2} \mathrm{P}(=\mathrm{O}) \mathrm{Cl}\right]$, and chlorothiophosphinates $\left[\mathrm{R}_{1} \mathrm{R}_{2} \mathrm{P}(=\mathrm{S}) \mathrm{Cl}\right]$ at the B3LYP/6-31I+G(d,p) level to compare the structurereactivity relationships.

\section{Results and Discussion}

The observed pseido-lirst-order rate constants ( $\left.k_{\text {stowid }}\right)$ for the reactions obeyed eq. (2) with negligible $k_{0}(=0)$ in acetonitrile. The second-order rate constants, $k_{3}(1)$, were determined using eq. (2) with at least five aniline concentrations, $[A n]$. No third-order or higher-order terms were 
Table 1. Second-Order Rate Constants, $k_{\mathrm{H}}$ and $k_{\mathrm{D}}\left(\times 10^{4} / \mathrm{M}^{-1} \mathrm{~s}^{-1}\right)$, of the Aminolysis of Diphenyl Thiophosphinic Chloride (2) with $\mathrm{XC}_{6} \mathrm{H}_{4} \mathrm{NH}_{2}$ and $\mathrm{XC}_{6} \mathrm{H}_{4} \mathrm{ND}_{2}$ in Acetonitrile at $55.0^{\circ} \mathrm{C}$

\begin{tabular}{cccc}
\hline $\mathrm{X}$ & $k_{T \mathrm{I}^{4}}$ & $k_{\mathrm{D}}{ }^{b}$ & $k_{\mathrm{T}} / k_{\mathrm{D}}$ \\
\hline $4-\mathrm{MeO}$ & $86.6 \pm 2.4^{6}$ & $78.8 \pm 1.7$ & $1.10 \pm 0.04$ \\
$4-\mathrm{Me}$ & $23.1 \pm 0.6$ & $21.2 \pm 0.5$ & $1.09 \pm 0.04$ \\
$3-\mathrm{Me}$ & $10.7 \pm 0.1$ & $10.2 \pm 0.2$ & $1.05 \pm 0.02$ \\
$\mathrm{H}$ & $6.01 \pm 0.12$ & $5.99 \pm 0.15$ & $1.00 \pm 0.03$ \\
$4-\mathrm{F}$ & $3.78 \pm 0.07$ & $3.71 \pm 0.09$ & $1.02 \pm 0.03$ \\
$4-\mathrm{Cl}$ & $0.572 \pm 0.013$ & $0.541 \pm 0.012$ & $1.06 \pm 0.03$ \\
$3-\mathrm{Cl}$ & $0.246 \pm 0.006$ & $0.232 \pm 0.005$ & $1.06 \pm 0.04$ \\
\hline
\end{tabular}

"Correlation coefficients (r) were betler than 0.998. $r>0.998$. "Standatd deviation.

detected, and no complications were found in the

$$
k_{\text {ohsd }}=k_{0}+k_{\mathrm{H}(\mathrm{D})}[\mathrm{An}]
$$

determination of $k_{\text {obsd }}$ or in the linear plots of eq. (2). This suggests that there is no base-catalysis or noticeable side reaction, and that the overall reactions follow the route given by eq. (1). The $k_{\mathrm{I}}$ values are summarized in Table I, together with the $k_{\mathrm{D}}$ values involving deuterated anilines $\left(\mathrm{XC}_{6} \mathrm{H}_{4} \mathrm{ND}_{2}\right)$.

In agreement with the trends for typical nucleophilic substitution reactions, the rates are faster with stronger nucleophiles. Figure 1 shows the rate ratios of the anilinolysis of $1,2,3$, and 4 in acetonitrile at $55.0^{\circ} \mathrm{C}$. The reaction rate of $1^{\text {td }}$ is 2.9 times faster than that of 2 , while the rate of $3^{+a}$ is 8.8 times faster than that of $4^{4^{c}}$ Phosphate systems are more reactive than their thiophosphate counterparts by one or more orders of magnitude, ${ }^{6}$ while phosphinate systems are less sensitive to $\mathrm{S}$ substitution in the $\mathrm{P}=\mathrm{O}$ bond compared to phosphate systems, ${ }^{7}$ in accordance with our results. The $\mathrm{P}=\mathrm{O}$ systems are generally more reactive than their $\mathrm{P}=\mathrm{S}$ counterparts for several reasons, the so-called thio effect, which is mainly the electronegativity difference between $\mathrm{O}$ and $\mathrm{S}$ and favors $\mathrm{O}$ over $\mathrm{S}{ }^{8}$

The phenoxy group $\left(\sigma_{l}=0.40\right.$ ) has stronger electronwithdrawing ability than the phenyl group $\left(\sigma_{I}=0.12\right){ }^{9}$ Solely considering the difference of inductive effects between the phenoxy and phenyl groups, the positive charge of the reaction center $P$ in 1 (and 2 ) would be smaller than that in 3 (and 4). Figure 1 shows the $\mathrm{NBO}$ charges on reaction center $\mathrm{P}, 1.844$ (1), 2.230 (3); 1.236 (2), 1.661 (4). The NBO charges on reaction center $P$ are consistent with the expectations for the inductive effects. If the rate is proportional to the positive charge on reaction center $\mathrm{P}$, the rate ratios should be $k_{\mathrm{p}=\mathrm{O}}(1) / k_{\mathrm{p}=\mathrm{O}}(3)<\mathrm{I}$ and $k_{\mathrm{p}=\mathrm{s}}(2) / k_{\mathrm{p}=\mathrm{s}}(4)<\mathrm{I}$. However, to the contrary, rate ratios of $k_{\mathrm{p}=\mathrm{O}}(1) / k_{\mathrm{p}=\mathrm{O}}(3)=1.9$ and $k_{\mathrm{p}=\mathrm{s}}(2) /$ $k_{\mathrm{p}=\mathrm{S}}(4)=6$ are obtained. These kinetic results imply that the reaction rate does not depend only on the magnitude of the positive charge on reaction center $P$.

Selectivity parameters, $\rho_{\mathrm{X}}$ and $\beta_{\mathrm{X}}$, and deuterium kinetic isotope effects (KIEs), $\hat{A}_{i} k_{0} \times$ are summarized in Table 2. The magnitudes of Hammett $\rho_{\mathrm{X}}(-3.97)$ and Brönsted $\beta_{\mathrm{X}}$ (1.40) values of 2 are both large, suggesting extensive bond formation in the TS. However, these values are somewhat smaller than those of $1, \rho_{x}(\mathbf{1})=-4.78$ and $\beta_{X}(\mathbf{1})=1.69{ }^{4 d}$ indicating a lesser degree of bond-formation in the anilinolysis of 2 compared to that of 1 . Figure 2 shows the Brinsted plots of the reactions of 2 with $\mathrm{XC}_{4} \mathrm{H}_{4} \mathrm{NH}_{2}$ and $\mathrm{XC}_{4} \mathrm{H}_{4} \mathrm{ND}_{3}$ in acetonitrile. The magnitudes of $\rho_{\mathrm{X}}$ and $\beta_{\mathrm{X}}$ values of $2(-3.94$ and 1.40 , respectively) with deuterated anilines $\left(\mathrm{XC}_{6} \mathrm{H}_{4} \mathrm{ND}_{2}\right)$ are nearly the same as those with anilines $\left(\mathrm{XC}_{6} \mathrm{H}_{4} \mathrm{NH}_{2}\right)$, while the magnitudes of $\rho \mathrm{x}$ and $\beta_{\mathrm{x}}$ values of $1(-4.56$ and 1.62 , respectively) with deuterated anilines are somewhat smaller than those with anilines. The $\mathrm{p} K_{\mathrm{a}}$ values of anilines in water are used to obtain the Brünsted $\beta_{\mathrm{X}}$ values and are
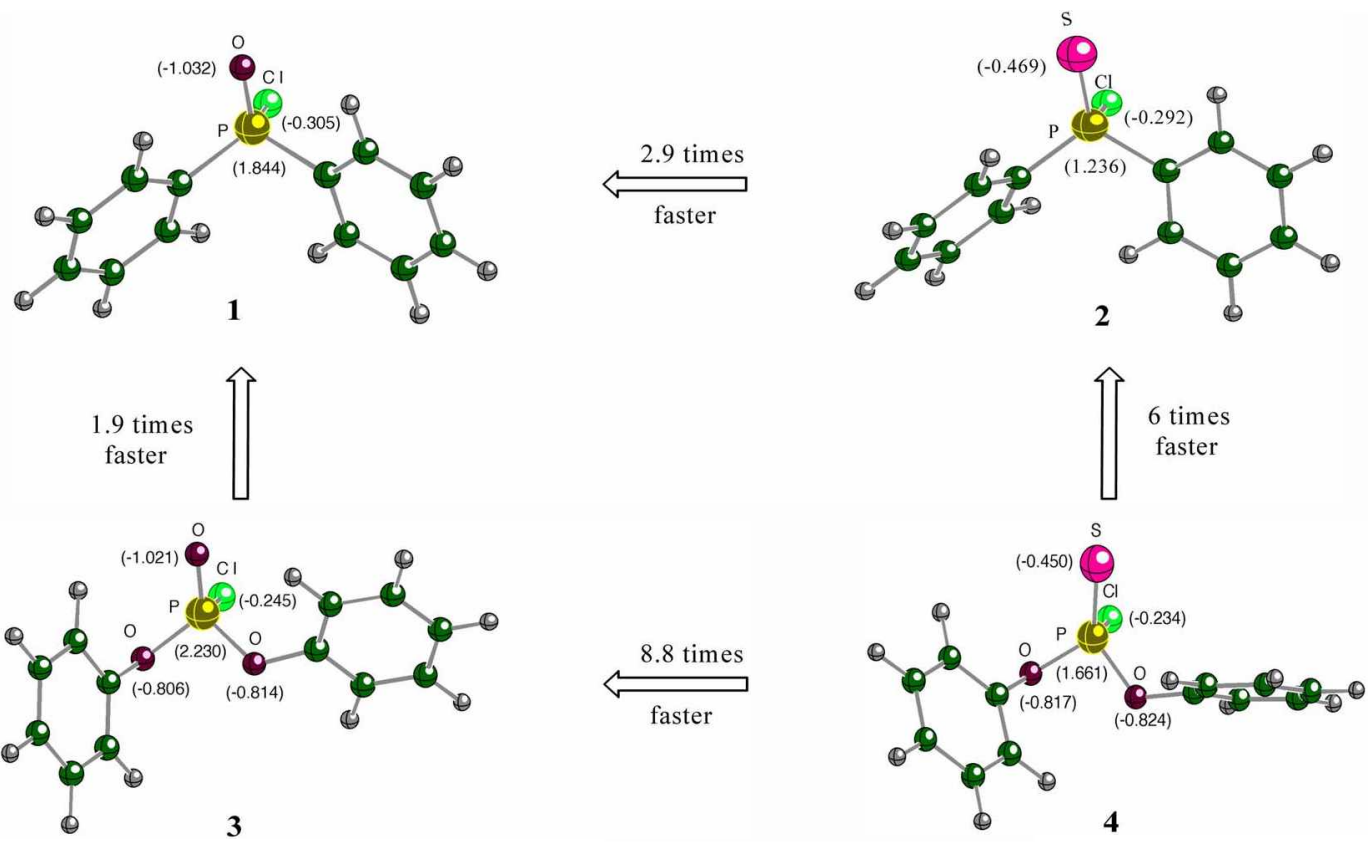

Figure 1. The B3LYP/6-311+G(d,p $)^{5}$ geometries and NBO charges of $1,4,2,3$, anc and $4{ }^{\text {tc }}$ The relative rate ratios are for unsubstituted aniline $\left(\mathrm{C}_{6} \mathrm{H}_{5} \mathrm{NH}_{2}\right)$. 
Table 2. The $k_{n}\left(\times 10^{+} / \mathrm{M}^{1} \mathrm{~s}^{4}\right), \rho_{x} . \beta_{x}$, and $\left.k_{1} / k_{0}\right)$ values of the

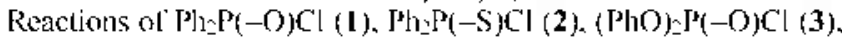
and $(\mathrm{PhO})_{2} \mathrm{P}(-\mathrm{S}) \mathrm{Cl}(4)$ with $\mathrm{X}-\Lambda$ nilines in $\Lambda$ cetonitrile at $55.0^{\circ} \mathrm{C}$

\begin{tabular}{|c|c|c|c|c|c|}
\hline Substrate & $k \|^{a}$ & $-p \mathrm{X}^{\prime}$ & $\beta x^{\circ}$ & $k_{\left[1 / k_{13}\right.}$ & ref. \\
\hline I & 17.3 & $4.78^{d}(4.56)^{\prime}$ & $1.69^{\prime \prime}(1.62)^{\prime}$ & $1.42-1.82$ & $4 d$ \\
\hline 2 & 6.01 & $3.97^{d}(3.94)^{r}$ & $1.40^{i}(1.40)^{r}$ & $1.00-1.10$ & This work \\
\hline 3 & 8.91 & 3.74 & 1.35 & $0.71-0.77$ & $4 a$ \\
\hline 4 & 1.01 & 3.88 & 1.36 & $1.11-1.27$ & $4 c$ \\
\hline
\end{tabular}

"When $X$ II. "The $\sigma$ values were taken from ref. 10 . "The $p K_{\text {a }}$ values were taken from ref, 11, "Calculated from $k_{1}$ values. "Calctlated from $k_{r}$, values.

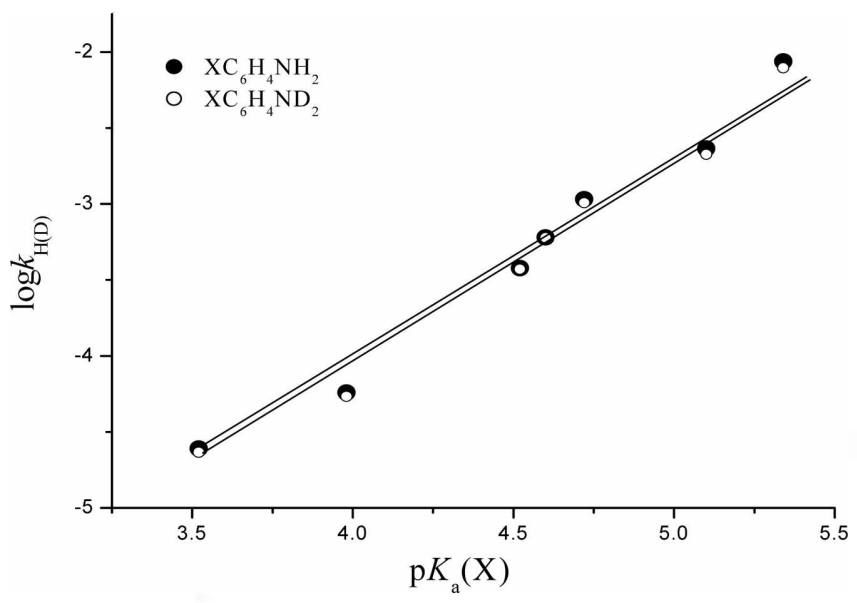

Figure 2, Bronsted plots of the anilinolysis of diphenyl thiophosphinic chloride (2) with $\mathrm{XC}_{6} \mathrm{H}_{4} \mathrm{NII}_{2}$ and $\left.\mathrm{XC}_{4} \mathrm{H}_{4} \mathrm{NI}\right)_{2}$ in actonitrile at $55.0^{\circ} \mathrm{C}$. The $p K_{i 1}$ values of $\mathrm{XC}_{6} \mathrm{H}_{4} \mathrm{ND}_{2}$ are assumed to be the same as those of $\mathrm{XC}_{6} \mathrm{H}_{4} \mathrm{NH}_{2}$ in water.

justified experimentally and theoretically. ${ }^{12}$ The obtained $\beta_{\mathrm{X}}$ value is larger than those of other phosphoryl and thiophosphoryl reactions in which the reactions proceed through a concerted mechanism $\left(\beta_{\mathrm{X}}=0.2-0.5\right)$. ${ }^{2.13}$. The $\beta_{\mathrm{X}}$ values of the reactions of (i) 4-nitrophenyl dimethyl phosphinothioate with phenoxides, ${ }^{2 b}$ (ii) 4-nitrophenyl diphenyl phosphate with phenoxides, ${ }^{13 \mathrm{~s}}$ (iii) 4-nitrophenyl diphenyl phosphinate with phenoxides, ${ }_{1}^{13 h}$ (iv) isocuinolino- $N$-phosphonate with pyridines, ${ }^{13 .}$ and (v) $O, O$-dimethyl $O$-(3-methyl-4-nitrophenyl) phosphorothioate with phenoxides ${ }^{13 \mathrm{~d}}$ are $0.47,0.53$, $0.46,0.15$, and 0.49 , respectively. The $\beta_{X}$ (and $\beta_{X}$ ) values of the anilinolysis of 3 and 4 are 1.35 (and 3.74$)^{\text {tu }}$ and 1.36 (and $3.88)$, ${ }^{\text {th }}$ respectively, somewhat smaller than that of 1 . The especially large $\rho_{\mathrm{X}}$ and $\beta_{\mathrm{X}}$ values seem to be characteristic of the anilinolysis of 1-4 in acetonitrile with their $\mathrm{Cl}$ leaving group.

In the anilinolysis of $\mathbf{3}$, a backside nucleophilic attack concerted mechanism with a late, product-like TS was proposed on the basis of large $\rho_{\mathrm{X}}$ (and $\beta \times$ ), large negative cross-interaction constant, ${ }^{14} \rho_{\mathrm{XY}}=-1,31$, and the secondary inverse $\mathrm{KIFs}, k_{\mathrm{H}} / k_{\mathrm{I}}$ ) $=0.7-0.8$, with deuterated aniline mucleophiles. ${ }^{\text {tu }}$ In the anilinolysis of $\mathbf{4}$, a partial frontside nucleophilic attack concerted mechanism through a hydrogen-bonded four-center type TS was suggested for several reasons, mainly based on the primary KIEs, kithe $=1.1$ $1.3^{\text {th }}$ In the anilinolysis of 1 , the greater kin $k$ he $(=1,4-1,8)$ values compared to those of $\left.4\left(k_{\mathrm{l}} / k_{0}\right)=1.1-1.3\right)$ were rationalized by the larger proportion of frontside nucleophilic attack compared to that of 4 . In the anilinolysis of 2 , both (i) frontside atack through a hydrogen-bonded fourcenter type TS (5) and (ii) backside attack concerted mechanism through TBP-5C TS (6) are suggested for the same reasons as in 1 and $\mathbf{4}^{\text {+4...' }}$

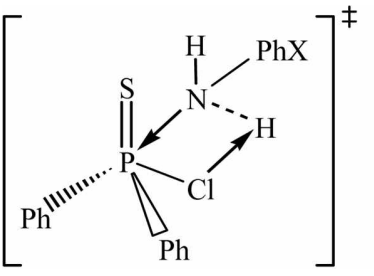

(5)

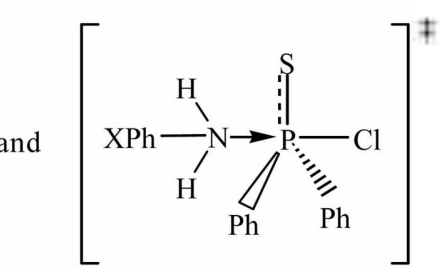

(6)
The observed primary KIISs in 2 would be the sum of (i) the primary normal KIE, $h_{H} / h_{0}>1$, because of partial deprotonation of one of the two $\mathrm{V}-\mathrm{I}$ ( $(\mathrm{D})$ bonds in TS 5 for a Irontside altack, (ii) the secondary inverse $\mathrm{KIF}, k_{\mathrm{H}} / k_{\mathrm{j}}, 1$, because of steric hindrance that increases the out-of-plane bending vibrational frequencies of the other $\mathrm{N}-\mathrm{l} \mathrm{l}(\mathrm{D})$ bond in TS 5 for a frontside attack, (iii) the secondary inverse KIE, $k_{4} / h_{0}<1$, because of steric congestion that increases the vibrational lrequencies of both of the N-II(D) bonds in TS 6 for a backside attack, (iv) decreased $k_{1} / k_{\text {I }}$, value because of the nonlinear and unsymmetrical structure of $\mathrm{N} \cdots \mathrm{II}(\mathrm{D}) \cdots \mathrm{Cl}$ in TS 5 , and finally (v) decreased $k_{1} / k_{1}$, value because of heavy atom ( $\mathrm{N}$ and $\mathrm{Cl}$ ) contribution to the reaction-coordinate motion. ${ }^{15}$ Thus, the real primary KIF, due to the hydrogen bond between the hydrogen of the $\mathrm{N}-\mathrm{I}(\mathrm{D})$ moiety and the Cl leaving group should be greater than the observed value.

The smaller kiphe values in $\mathbf{2}$ compared to those in $\mathbf{1}$ may be attributed to the smaller proportion of frontside attack in 2 than in 1 or to a lesser degree of bond-formation in 2 than in 1 , assuming the primary KIE, is proportional to the degree of bond-formation. Considering the relatively large steric hindrance on the backside attack toward the $\mathrm{Cl}$ leaving group due to two phenyl rings in the reactions of $\mathbf{1}$ and $\mathbf{2}$ with anilines, a lesser degree of bond-fomation in 2 than in $\mathbf{l}$ is more reasonable, which leads to smaller primary KIFis. This suggestion is consistent with the smaller $\rho_{\mathrm{X}}$ and $\beta_{\mathrm{X}}$ values of 2 compared to these of 1 , and with the smaller NBO charge on $P$ in $2(1.236)$ than in $1(1.844)$ as shown in Figure I.

Another possible TS structure could be TS 7 where there is a hydrogen bond between the sulfur atom in $\mathrm{P}=\mathrm{S}$ and the hydrogen of the N-II(D) moiety in aniline. $A$ four-membered TS 8 was proposed in the ethanolysis of the phosphinates, paraxon, and parathion with alkali metal ions by Buncel and his coworkers, and Um and his coworkers."

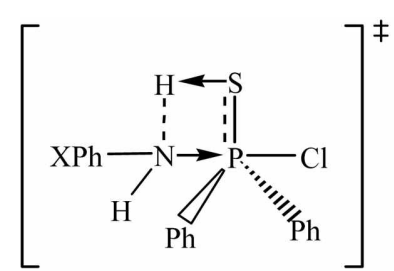

( 7 )
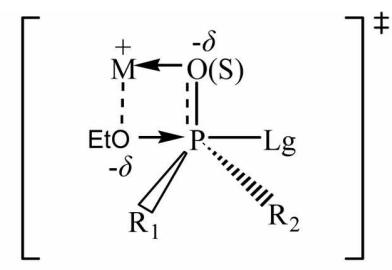

( 8 ) 
I Iowever, positive charge development on the hydrogen of the N-II moiety in the TS would be much smaller than that of $\mathrm{M}^{-}$ions, so hydrogen bond involving the polarizable aceptor $\mathrm{P}=\mathrm{S}$, as in $\mathrm{TS} 7$, is not feasible. In addition, the secondary inverse KIF: in $3^{\text {tu }}$ cannot be substantiated by TS 7. Moreover, the rate ratio of $k \mathrm{p}-\mathrm{s}(2) / k_{\mathrm{p}-\mathrm{s}}(4)=6$ cannot be rationalized by the backside attack (TS 7), despite the larger NBO charge on $P$ in 4 (1.661) than in $2(1.236)$, since the steric hindrance on the backside attack TS would be larger in $\mathbf{2}$ than in $\mathbf{4}$ due to the intervening oxygen atom between the reaction center $\mathrm{P}$ atom and the phenyl group in $\mathbf{4}$.

The NBO charges on $P$ of various $R_{1} R_{2} P(=O$ or $=S) C$ l derivatives (42 consounds), calculated at the B3LYP/6$311+\mathrm{G}(\mathrm{d}, \mathrm{p})$ level, ${ }^{5}$ are summarized in Table 3 , and the plots of NBO charges on $P$ against $\Sigma \sigma_{1}$ are shown in Figure 3. The slopes for $\mathrm{P}=\mathrm{O}$ and $\mathrm{P}=\$$ systems are 0.63 (multiple correlation coeflicient, $r=0.946)$ and $0.71(r=0.936)$, respectively. The plots show the evident discontinuities between families: $A\left[\left(\mathrm{R}_{1} \mathrm{O}\right)\left(\mathrm{R}_{2} \mathrm{O}\right) \mathrm{P}(=\mathrm{L}) \mathrm{Cl}\right.$; cntry no. 1-6], $B\left[\left(\mathrm{R}_{1} \mathrm{O}\right) \mathrm{R}_{2} \mathrm{P}-\right.$ $(=\mathrm{L}) \mathrm{Cl}$; entry no. 7-15], and $C\left[\mathrm{R}_{3} \mathrm{R}_{2} \mathrm{P}(=\mathrm{L}) \mathrm{Cl}\right.$; entry no. 16-21].

The NBO charge on $P$ of $P=O$ system is larger than that of its $\mathrm{P}=\mathrm{S}$ counterpart due to the larger electronegativity of $\mathrm{O}$ compared to that of $S$. The relative ratio of NBO charges on $\mathrm{P}$ for $\mathrm{P}=\mathrm{O}$ and its $\mathrm{P}=\mathrm{S}$ counterpart, $q \mathrm{P}-0 / q \mathrm{p}-\mathrm{S}$, are $1.31-1.34$ (Jamily $A$ ) $<1.39-1.4 !$ (fanily $B)<1.49-1.52$ (family $C$. The magnitudes of positive NBO charges on $\mathrm{P}$ are $A>B>C$ with the same $R_{1}$ and $R_{2}$, e.g., $2.230\left[(\mathrm{PhO})_{2} \mathrm{P}(=\mathrm{O}) \mathrm{Cl}\right]>$

Table 3. NBO Charges on P. Calculated at the B3LYP/6-3I1+G (d.p) level, of $\mathrm{R}_{1} \mathrm{R}_{2} \mathrm{P}(=\mathrm{L}) \mathrm{Cl}$

\begin{tabular}{|c|c|c|c|c|c|}
\hline entry & $R_{1}$ & $\mathrm{R}_{2}$ & $\Sigma \sigma$ & $I_{0}=O^{h}$ & $\mathrm{I}=\mathrm{S}^{\circ}$ \\
\hline 1 & $\mathrm{PhO}$ & $\mathrm{PhO}$ & 0.80 & $2.230^{i}$ & $1.661^{\circ}$ \\
\hline 2 & Pho & $\mathrm{MeO}$ & 0.70 & 2.248 & 1.686 \\
\hline 3 & Pho & lito & 0.68 & 2.233 & 1.687 \\
\hline 4 & $\mathrm{McO}$ & $\mathrm{MeO}$ & 0.60 & 2.226 & 1.687 \\
\hline 5 & $\mathrm{MeO}$ & Eto & 0.58 & 2.231 & 1.693 \\
\hline 6 & $\operatorname{lit} 0$ & lito & 0.56 & $2.236^{i}$ & $\mathrm{I} .70 \mathrm{I}^{\prime}$ \\
\hline 7 & $\mathrm{PhO}$ & Ph & 0.52 & 2.043 & 1.462 \\
\hline 8 & $\mathrm{MeO}$ & $\mathrm{Ph}$ & 0.42 & 2.049 & 1.472 \\
\hline 9 & teto & $\mathrm{Ph}$ & 0.40 & 2.054 & 1.478 \\
\hline 10 & $\mathrm{PhO}$ & Et & 0.39 & 2.027 & 1.445 \\
\hline 11 & $\mathrm{PhO}_{\mathrm{H}}$ & Me & 0.39 & 2.017 & 1.432 \\
\hline 12 & $\mathrm{MeO}$ & Et & 0.29 & 2.030 & 1.456 \\
\hline 13 & $\mathrm{MeO}$ & $\mathrm{Me}^{2}$ & 0.29 & 2.019 & 1.441 \\
\hline 14 & Eto & $\mathrm{Et}$ & 0.27 & 2.036 & 1.462 \\
\hline 15 & Eto & $M e$ & 0.27 & 2.024 & 1.447 \\
\hline 16 & $\mathrm{Ph}$ & $\mathrm{Ph}$ & 0.24 & $1.844:$ & $1.236^{h}$ \\
\hline 17 & l'h & r.t & 0.11 & 1.833 & 1.224 \\
\hline 18 & $\mathrm{Ph}$ & $\mathrm{M}$ & 0.11 & 1.821 & 1.210 \\
\hline 19 & Et & Et & -0.02 & 1.817 & 1.208 \\
\hline 20 & Ft. & $\mathrm{Me}^{2}$ & -0.02 & 1.805 & 1.194 \\
\hline 21 & $\mathrm{Me}$ & $\mathrm{Mk}^{\mathrm{i}}$ & -0.02 & 1.793 & 1.180 \\
\hline
\end{tabular}

"The $\sigma$ values of pho, Meo, Eto, I'/, I:t, and Me are $0.40,0,30,0,28$, $0.12,-0.01$, and -0.01 , mespectively, taken from tef. 9 . $\mathrm{N} 130$ charges on P' when I. $-O$. "NI3O charges on $\mathrm{P}$ when $\mathrm{I}, \mathrm{S}$. "Ret, 4al, c. "Rel. $4 \mathrm{c}$. ReE. 4 c. "Red" 4 al. "Rel" 4 i.

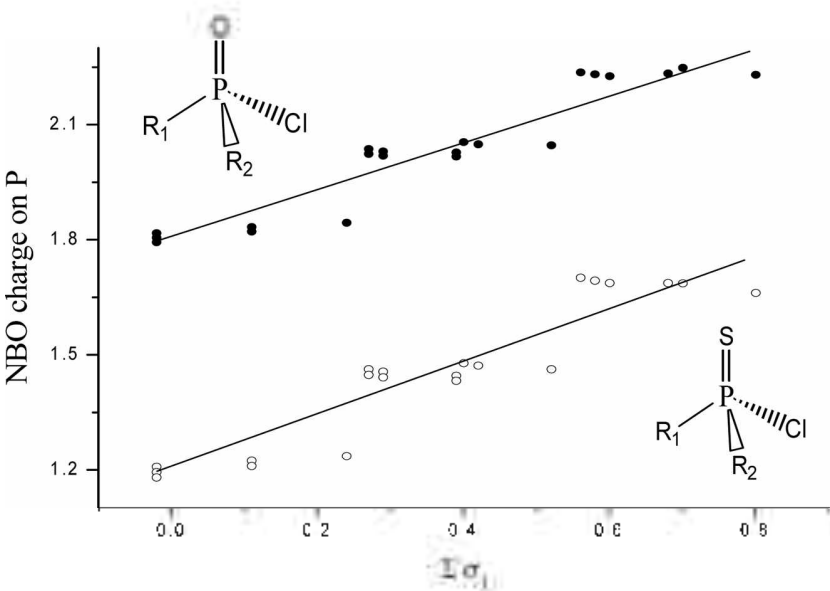

Figure 3. The plots of ABO charges on P. calculated at the B.SLY' $6-311 ! \mathrm{G}\left(\alpha_{1}\right)$ ) level. against $\Sigma \sigma_{1}$.

$2.043[(\mathrm{PhO}) \mathrm{PhP}(=\mathrm{O}) \mathrm{Cl}]>1.844\left[\mathrm{Ph}_{2} \mathrm{P}(=\mathrm{O}) \mathrm{Cl}\right]$ and 1.661 $\left[(\mathrm{PhO})_{2} \mathrm{P}(=\mathrm{S}) \mathrm{Cl}\right]>1.462 \quad[(\mathrm{PhO}) \mathrm{PhP}(=\mathrm{S}) \mathrm{Cl}]>1.236$ [ $\mathrm{Ph}-\mathrm{P}(=\mathrm{S}) \mathrm{Cl}]$. Intervening oxygen atoms between $\mathrm{R}$ and $\mathrm{P}$ increase the magnitude of positive charge on $P$, but decrease the relative ratio of positive chareses on $\mathrm{P}, q_{\mathrm{P}} \mathrm{o} / q^{\mathrm{p}}$, , for $\mathrm{P}=\mathrm{O}$ and its $\mathrm{P}=\mathrm{S}$ counterpart. Figure 4 shows the plots of the second-order rate constant $\left(k_{\mathrm{T}}\right)$ against $\mathrm{NBO}$ charge on $\mathrm{P}$ for the anilinolysis of diphenyl chlorophosphate, ${ }^{+4} 4$-chlorophenyl phenyl chlorophosphate, ${ }^{\text {th }}$ phenyl ethyl chlorophosphate, ${ }^{4 \cdot}$ and diphenyl phosphinic chloride, ${ }^{\text {td }}$ and their $\mathrm{P}=\mathrm{S}$ counterparts ${ }^{4 t .4}$ in acelonitrile at $55.0^{\circ} \mathrm{C}$. Sterie effects on the reaction rates and the altacking direction, backside or frontside, are the main factors that lead to bad correlation (even negative slope) between he and NBO charges on P of $\mathrm{P}=\mathrm{O}$ and $\mathrm{P}=\mathrm{S}$ systems.

The degree of distortion of $\mathrm{R}_{1} \mathrm{R}_{2} \mathrm{P}(=\mathrm{O}$ or $=\mathrm{S}) \mathrm{Cl}$ from the regular tetrahedral structure can be defined as eq. (3), ${ }^{\text {te }}$

$$
\Delta \delta=\Sigma\left|\theta_{c}-\theta_{i}\right| / \theta_{i}=\Sigma\left|\theta_{c}-109.5\right| / 109.5
$$

where $A \delta$ is the degree of distortion, $\Sigma$ means the sum of all of six bond angles, $\theta_{c}$ is the calculated bond angle at the

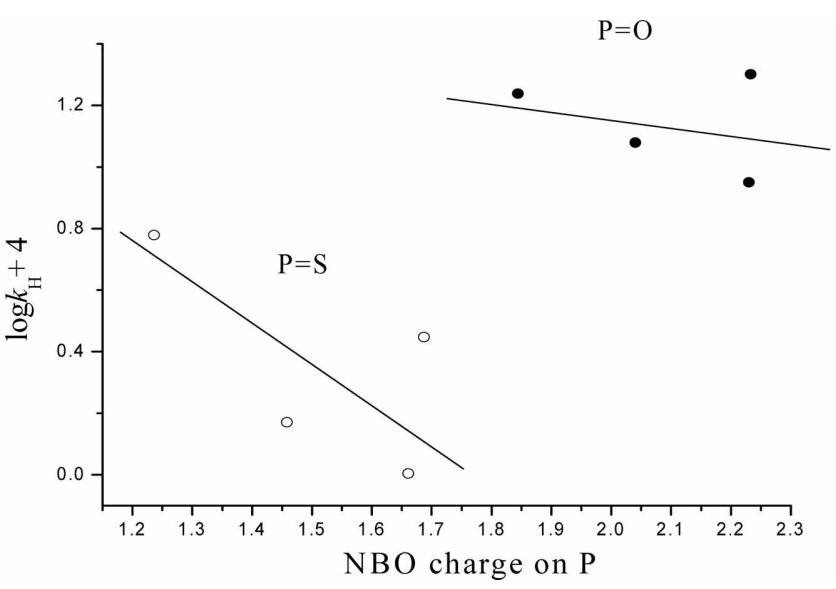

Figure 4. The plots of logk (in acetonitrile at $55.0^{\circ} \mathrm{C}$ ) against VBO charges on P for the anilinolysis of diphenyl chlorephosphate, ${ }^{\text {t1 }}$ 4-chlorophenyl phenyl chlorophosphate, ${ }^{40}$ phenyl ethyl chlorophosphate, ${ }^{+6}$ and diphenyl phosphinic chloride. ${ }^{41}$ and their $P=S$ counterparls. ${ }^{k}$ : 
Table 4. Bond $A$ ngles and Degrees of Distortion, Calculated at the $\mathrm{B} 3 \mathrm{LYP} / 6-311+\mathrm{G}(\mathrm{d}, \mathrm{p})$ level, ${ }^{5}$ of $\mathrm{R}_{1} \mathrm{R}_{2} \mathrm{P}(=\mathrm{L}) \mathrm{Cl}$ in the Gas Phase

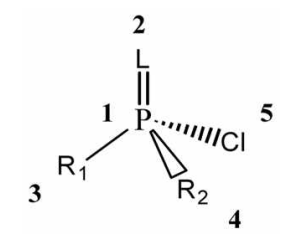

\begin{tabular}{|c|c|c|c|c|c|}
\hline entry & L & $\mathrm{R}_{\mathbf{I}}$ & $\mathrm{R}_{2}$ & $\angle 213 \angle 214 \angle 215 \angle 314 \angle 415 \angle 315$ & $\Delta d$ \\
\hline 10 & O & $\mathrm{PhO}$ & $\mathrm{PhO}$ & $118.5 \quad 116.7 \quad 113.9100 .7 \quad 104.899 .8$ & $0.40^{4}$ \\
\hline $1 \mathrm{~S}$ & $S$ & $\mathrm{PhO}$ & $\mathrm{PhO}$ & $\begin{array}{llllll}119.4 & 117.9 & 115.8 & 99.4 & 103.4 & 97.5\end{array}$ & $0.48^{a}$ \\
\hline 20 & o & $\mathrm{PhO}$ & $\mathrm{MeO}$ & $114.9 \quad 118.0 \quad 112.9 \quad 101.2 \quad 103.0105 .2$ & 0.33 \\
\hline $2 \mathrm{~S}$ & $s$ & $\mathrm{PhO}$ & $\mathrm{MeO}$ & 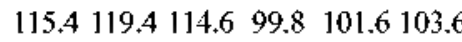 & 0.41 \\
\hline 30 & 0 & $\mathrm{PhO}$ & Eto & $118.1 \quad 116.0 \quad 114.1 \quad 101.2104 .3100 .9$ & $0.38^{\prime \prime}$ \\
\hline $3 \mathrm{~S}$ & $s$ & $\mathrm{PhO}$ & Eto & $\begin{array}{llllll}119.0 & 117.4 & 115.3 & 99.9 & 103.4 & 98.8\end{array}$ & $0.45^{a}$ \\
\hline 40 & O & $\mathrm{MeO}$ & $\mathrm{MeO}$ & $\begin{array}{llllll}118.3 & 115.5 & 113.8 & 102.1 & 104.8 & 100.3\end{array}$ & 0.37 \\
\hline $4 \mathrm{~s}$ & $\mathbf{S}$ & $\mathrm{MeO}$ & $\mathrm{MeO}$ & $119.1 \quad 116.7 \quad 115.4 \quad 100.7 \quad 103.598 .5$ & 0.44 \\
\hline 50 & O & $\mathrm{MeO}$ & Eto & $\begin{array}{llllll}118.1 & 115.8 & 113.7 & 102.3 & 104.6 & 100.2\end{array}$ & 0.37 \\
\hline $5 \mathrm{~S}$ & $\mathrm{~s}$ & $\mathrm{MeO}$ & Eto & 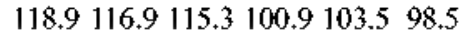 & 0.44 \\
\hline 60 & o & Eto & Eto & 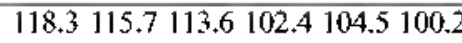 & 0.37 \\
\hline $6 \mathrm{~S}$ & $S$ & Eto & Eto & $118.9116 .8 \quad 115.0 \quad 101.4103 .498 .6$ & 0.43 \\
\hline 70 & o & $\mathrm{PhO}$ & $\mathrm{Ph}$ & 115.9117 .7111 .9101 .8102 .0105 .9 & 0.33 \\
\hline $7 \mathrm{~S}$ & $\mathrm{~s}$ & PhO & $\mathrm{Ph}$ & $118.4118 .4 \quad 113.0 \quad 99.8 \quad 101.4103 .3$ & 0.41 \\
\hline 80 & o & $\mathrm{MeO}$ & $\mathrm{Ph}$ & $116.5 \quad 117.4 \quad 111.2 \quad 102.6102 .2105 .2$ & 0.32 \\
\hline $8 \mathrm{~S}$ & S & $\mathrm{MeO}$ & $\mathrm{Ph}$ & 118.5117 .9112 .8100 .8101 .0103 .3 & 0.40 \\
\hline 90 & $\mathrm{O}$ & Eto & $\mathrm{Ph}$ & $116.3 \quad 117.5 \quad 111.2 \quad 102.8102 .3105 .0$ & 0.32 \\
\hline $9 \mathrm{~s}$ & s & Eto & $\mathrm{Ph}$ & 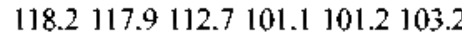 & 0.40 \\
\hline 100 & o & PhO & Et & $117.4117 .3 \quad 111.8 \quad 100.5103 .0105 .0$ & 0.35 \\
\hline $10 \mathrm{~S}$ & $\mathrm{~S}$ & PhO & $\mathrm{Et}$ & $\begin{array}{lllll}118.9 & 118.4113 .4 & 98.4 & 102.3 & 102.7\end{array}$ & 0.43 \\
\hline 110 & o & PhO & $\mathrm{Me}$ & 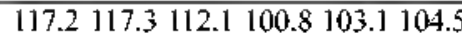 & 0.35 \\
\hline $11 \mathrm{~S}$ & $\$$ & Pho & $\mathrm{Me}$ & $\begin{array}{llll}118.5 & 118.5 \quad 113.7 \quad 99.0 & 102.3 & 102.0\end{array}$ & 0.43 \\
\hline 120 & o & $\mathrm{MeO}$ & Et & $118.0116 .6111 .4 \quad 101.7103 .1104 .2$ & 0.34 \\
\hline $12 \mathrm{~S}$ & $\$$ & $\mathrm{MeO}$ & Et & 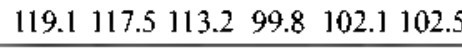 & 0.41 \\
\hline 130 & o & $\mathrm{MeO}$ & $\mathrm{Me}$ & 117.9116 .6111 .6101 .7103 .3103 .8 & 0.34 \\
\hline $13 \mathrm{~S}$ & $S$ & $\mathrm{MeO}$ & $\mathrm{Me}$ & $118.8 \quad 117.7 \quad 113.5 \quad 100.0102 .2102 .0$ & 0.42 \\
\hline 140 & o & Eto & Et & 117.7116 .9111 .3101 .9103 .1104 .2 & 0.34 \\
\hline $14 \mathrm{~S}$ & S & Eto & Et & 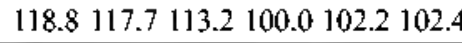 & 0.41 \\
\hline 150 & o & Eto & $\mathrm{Me}$ & 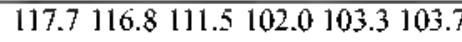 & 0.34 \\
\hline $15 \mathrm{~S}$ & $\mathrm{~S}$ & Eto & $\mathrm{Me}$ & $118.5117 .8113 .4 \quad 100.4102 .3101 .8$ & 0.41 \\
\hline 160 & o & $\mathrm{Ph}$ & $\mathrm{Ph}$ & 113.4112 .7113 .9110 .0102 .8103 .2 & 0.23 \\
\hline $16 \mathrm{~S}$ & $S$ & $\mathrm{Ph}$ & $\mathrm{Ph}$ & $115.3115 .0113 .5 \quad 107.4101 .3102 .6$ & 0.30 \\
\hline 170 & o & $\mathrm{Ph}$ & Et & $115.0 \quad 113.7 \quad 113.2 \quad 108.4103 .3101 .9$ & 0.26 \\
\hline $17 \mathrm{~S}$ & 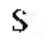 & $\mathrm{Ph}$ & Et & $115.9115 .8114 .4 \quad 106.0102 .1100 .6$ & 0.34 \\
\hline 180 & o & $\mathrm{Ph}$ & $\mathrm{Me}$ & $113.7115 .0113 .5 \quad 108.6101 .2103 .5$ & 0.26 \\
\hline $18 \mathrm{~S}$ & $\mathrm{~S}$ & $\mathrm{Ph}$ & $\mathrm{Me}$ & 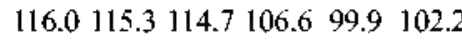 & 0.34 \\
\hline 190 & o & Et & Et & $114.8114 .7 \quad 113.7 \quad 107.6102 .8101 .9$ & 0.28 \\
\hline $19 S$ & S & Et & Et & $116.3116 .3114 .8 \quad 105.5100 .9100 .9$ & 0.37 \\
\hline 200 & $\mathrm{O}$ & Et & $\mathrm{Me}$ & 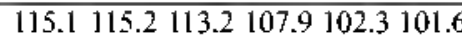 & 0.29 \\
\hline $20 \mathrm{~S}$ & $\mathrm{~s}$ & Et & $\mathrm{Me}$ & 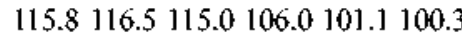 & 0.36 \\
\hline 210 & o & $\mathrm{Me}$ & $\mathrm{Me}$ & $115.1 \quad 115.1 \quad 113.5 \quad 108.0101 .7101 .7$ & 0.29 \\
\hline $21 \mathrm{~S}$ & $\mathrm{~S}$ & $\mathrm{Me}$ & $\mathrm{Me}$ & 115.9115 .9115 .4106 .3100 .5100 .6 & 0.36 \\
\hline
\end{tabular}

Rer. 4e.

B3LYP/6-31I $+\mathrm{G}(\mathrm{d}, \mathrm{p})$ leve $]^{5}$ and $\theta_{i}$ is the ideal bond angle $\left(109.5^{\circ}\right)$ of a regular tetrahedral structure. The $\Delta \delta$ values of 42 compounds are summarized in Table 4 together with six bond angles. Due to the larger size and polarizability of $\mathrm{P}=\mathrm{S}$ sulfur compared to those of $\mathrm{P}=\mathrm{O}$ oxygen, the distortion of $\mathrm{P}=\mathrm{S}$ substrates is larger than that of $\mathrm{P}=\mathrm{O}$ substrates. The increments of the degree of distortion from $\mathrm{P}=\mathrm{O}$ to $\mathrm{P} \Rightarrow \mathrm{S}$ counterparts are 1.17-1.21, 1.22-1.27, and 1.23-1.30 times larger for families $A, B$, and $C$, respectively. The larger the ligand, the greater the increment of degree of distortion, e.g., $\Delta \delta=0.400\left(\mathrm{R}_{1}=\mathrm{R}_{2}=\mathrm{PhO}\right), 0.327\left(\mathrm{R}_{1}=\mathrm{PhO}, \mathrm{R}_{2}=\mathrm{Ph}\right)$, and $0.228\left(\mathrm{R}_{1}=\mathrm{R}_{2}=\mathrm{Ph}\right)$.

\section{Summary}

The reactions of diphenyl thiophosphinic chloride (2) with $\mathrm{X}$-anilines were studied kinetically in acetonitrile at $55.0^{\circ} \mathrm{C}$. Structure-reactivity relationships between diphenyl phosphinic chloride (1), diphenyl chlorophosphate (3), and diphenyl chlorothiophosphate (4), were discussed based on NBO charges and steric effects. The primary normal KIEs involving deuterated aniline $\left(\mathrm{XC}_{6} \mathrm{H}_{4} \mathrm{ND}_{2}\right)$ nucleophiles were obtained and were consistent with a partial frontside attack concerted mechanism through a hydrogen-bonded fourcenter type TS. The smaller magnitudes of $\rho_{\mathrm{X}}$ and $\beta_{\mathrm{X}}$ values of 2 compared to those of 1 suggest a lesser degree of bondformation in the TS. The NBO charge on $\mathrm{P}$ and the degree of distortion of $42 \mathrm{R}_{1} \mathrm{R}_{2} \mathrm{P}(=\mathrm{O}$ or $\Rightarrow \mathrm{S}) \mathrm{Cl}$ compounds were calculated at the B3LYP/6-31 I+G(d,p) level. The bad correlation between reaction rates and $\mathrm{NBO}$ charges on $\mathrm{P}$ was ascribed to steric effects and the attacking direction of the nucleophile.

\section{Experimental Section}

Materials. Diphenyl thiophosphinic chloride ( $\min .95 \%$ ) and $\mathrm{HPLC}$-grade acetonitrile (water content is less than $0.005 \%$ ) were used for kinetic studies without further purification. Anilines were redistilled or recrystallized before use as previously described. ${ }^{18}$ Deuterated anilines were synthesized by heating anilines and deuterium oxide $(99.9$ atom $\% \mathrm{D}$ ) at $90^{\circ} \mathrm{C}$ for 72 hours, and after numerous attempts, anilines were deuterated more than $98 \%$, as confinmed by ${ }^{1} \mathrm{H} \mathrm{NMR}$.

Kinetics Measurement. Rates were measured conductometrically as previously described. ${ }^{+}$[Substrate] $=0.001 \mathrm{M}$ and [Nucleophile] $=0.03-0.15 \mathrm{M}$ were used for the present work. Pseudo-first-order rate constant values were the average of three runs that were reproducible within $\pm 3 \%$.

Product Analysis. Diphenyl thiophosphinic chloride was reacted with excess anilines $\left(\mathrm{XC}_{6} \mathrm{H}_{4} \mathrm{NH}_{2} ; \mathrm{X}=4-\mathrm{CH}_{3}, \mathrm{H}\right)$ for more than 15 half-lives at $55.0^{\circ} \mathrm{C}$ in acetonitrile, as previously described. ${ }^{4 c}$ Analytical data of the products gave the following results:

$\left(\mathrm{C}_{6} \mathrm{H}_{5}\right)_{2} \mathrm{P}\left(=\mathrm{S}_{\mathrm{NHC}} \mathrm{NH}_{\mathbf{4}}-\mathbf{4}-\mathrm{CH}_{3}\right.$. Light-Brown solid; mp 169-171 ${ }^{\circ} \mathrm{C}$; IR(nujol mull): 3358 (NH), 3055 (C-H, aromatic), $2955\left(\mathrm{CH}_{3}\right), 1612,1516,1436,1104\left(\mathrm{P}-\mathrm{C}_{6} \mathrm{H}_{5}\right)$, $809(\mathrm{P}=\mathrm{S})$; 'H NMR $(400 \mathrm{MHz}, \mathrm{DMSO}-\mathrm{d} 6) \delta 2.22(3 \mathrm{H}, \mathrm{s}$, $\left.\mathrm{CH}_{3}\right), 6.79-6.81(2 \mathrm{H}, \mathrm{d}, J=8.0 \mathrm{~Hz}), 6.94-6.97(2 \mathrm{H}, \mathrm{d}, J=$ $12.0 \mathrm{~Hz}), 7.25-7.54(6 \mathrm{H}, \mathrm{m}$, phenyl), 7.98-8.04 $(4 \mathrm{H}, \mathrm{m}$, 
phenyl), 4.78-4.80 $(1 \mathrm{H}, \mathrm{d}, J=6.0 \mathrm{~Hz}, \mathrm{NH}) ;{ }^{13} \mathrm{C} \mathrm{NMR}(100$ MHz, DMSO-d6) $\delta 118.6-118.8\left(\mathrm{CH}_{3}, \mathrm{~d}, J=7.5 \mathrm{~Hz}\right), 128.4-$ $138.7\left(\mathrm{C}=\mathrm{C}\right.$, aromatic); ${ }^{31} \mathrm{P}$ NMR (162 MHz, DMSO-d6) $\delta$ $59.7(1 \mathrm{P}, \mathrm{s}, \mathrm{P}=\mathrm{S}) ; \mathrm{m} / \mathrm{z}, 323(\mathrm{M}+)$; Anal. Calcd for $\mathrm{C}_{19} \mathrm{H}_{18} \mathrm{NPS}$ : C, $70.57 ; \mathrm{H}, 5.61 ; \mathrm{N}, 4.33 ; \mathrm{S}, 9.92$. Found: C, 70.57; H, 5.61; $\mathrm{N}, 4.26 ; \mathrm{S}, 9.77$.

$\left(\mathrm{C}_{6} \mathrm{H}_{5}\right)_{2} \mathrm{P}(=\mathrm{S}) \mathrm{NHC}_{6} \mathrm{H}_{5}$. Fawn solid; mp 159-161 ${ }^{\circ} \mathrm{C}$; IR (nujol mull): 3124; (NH), 3054 (C-H, aromatic), 1602, 1479, $1437,1103\left(\mathrm{P}-\mathrm{C}_{6} \mathrm{H}_{5}\right), 797(\mathrm{P}=\mathrm{S}) ;{ }^{1} \mathrm{H}(400 \mathrm{MHz}, \mathrm{DMSO}-\mathrm{d} 6)$, $\delta 6.89-6.93(3 \mathrm{H}, \mathrm{m}$, phenyl), 7.13-7.17 $(2 \mathrm{H}, \mathrm{m}$, phenyl), 7.45-7.55 (6H, m, phenyl), 7.98-8.05 (4H, $\mathrm{m}$, phenyl), 4.87$4.89(1 \mathrm{H}, \mathrm{d}, J=6 \mathrm{~Hz}, \mathrm{NH}) ;{ }^{13} \mathrm{C}$ NMR $(100 \mathrm{MHz}$, DMSOd6) $\delta 118.5-141.3\left(\mathrm{C}=\mathrm{C}\right.$, aromatic); ${ }^{31} \mathrm{P}$ NMR $(162 \mathrm{MHz}$, DMSO-d6) $\delta 59.6(1 \mathrm{P}, \mathrm{s}, \mathrm{P}=\mathrm{S}) ; \mathrm{m} / \mathrm{z}, 309(\mathrm{M}+)$; Anal. Calcd for $\mathrm{C}_{18} \mathrm{H}_{16} \mathrm{NPS}$ : $\mathrm{C}, 69.88 ; \mathrm{H}, 5.21 ; \mathrm{N}, 4.53 ; \mathrm{S}, 10.37$. Found: C, $69.81 ; \mathrm{H}, 5.22 ; \mathrm{N}, 4.38 ; \mathrm{S}, 10.15$.

Acknowledgement. This work was supported by Inha University Research Grant.

\section{References}

1. (a) Corbridge, D. E. C. Phosphonts-An Outline of its Chemistry, Biochemistry and Uses, 5th ed.; Elsevier: Amsterdam, 1995; Chapter 11 . (b) Williams, A. Concerted Organic and Bio-Organic Mechanisms; CRC Press: Boca Raton, 2000. (c) Hudson, R. F. Strtcture and Mechanism on Organophosphorus Chemistry; Academic Press: New York, 1965.

2. (a) Humphry, T.; Forconi, M.; Williams, N. H.; Hengge, A. C. J. Am. Chem. Soc, 2004, 126, 11 864. (b) Onyido, I.; Swierczek, K.; Purcell, J.; Hengge, A. C. J. Am. Chem. Soc. 2005, 127,7703 . (c) Um, I. H.; Shin, Y. H.; Han, J. Y,; Mishima, M. J. Org. Chem. 2006, 71, 7715. (d) Skoog, M. T.; Jencks, W. P. J. Am. Chemi. Soc. 1984, 106, 7597. (e) Harger, M. J. P. J. Chen. Soc. Perkin Trants. 2 2002, 489. (f) Hengge, A. C. Ads. Phys. Org. Chem. 2005, 40, 49. (g) van Bochove, M. A.; Swar, M.; Bickelhaupt, M. J. Am. Chem. Soc. 2006, $/ 28,10738$.

3. (a) Hall, C. R.; Inch, T. D. Tetrahedron 1980, 36, 2059. (b) Rowell, R.; Gorenstein, D. G. J. Am. Chem. Soc. 1981, J03, 5894. (c) Inch, T. D.; Lewis, G. J.; Wilkinson, R. G; Watts, P. J. Chent. Soc. Chent. Conmitn. 1975, 500. (d) Inch, T. D.; Lewis, G. J. Carbohydrate Research, 1975, 45, 65. (e) Harrison, J. M.; Inch, T. D.; Lewis, G. J. J. Chem. Soc., Perkin 1 1974, 1053. (f) Stec, W. J.; Okruszek, A.; Lesiak, K.; Uznanski, B.; Michalski, J. J. Org. Chem. 1976, 41, 22. (g) Hall, C. R.; Inch, T. D. J. Chem. Soc., Perkin 1 1979, II04. (h) Hall, C. R.; Inch, T. D. J. Chem. Soc., Perkin I 1979, 1646. (i) Corriu, R. J. P.; Dutheil, J. P. Lanneau, G. F. J. Am. Chem. Soc, 1984, 106, 1060. (j) Corriu, R. J. P.; Dutheil, J. P.; Lanneau, G. F.; Leclercq, D. Tetrahedron Lett. 1983, 24, 4323. (k) Corriu, R. J. P.; Fernandez, J. M.; Guerin, C. Non: J. Chem. 1984, 8, 279. (l) Corriu, R. J. P.; Dutheil, J. P.; Lanneau, G. F.; Ould-Kada, S. Tetrahedron 1979, 35, 2089.

4. Anihlinohssis: (a) Guha, A. K.; Lee, H. W.; Lee, I. J. Chen. Soc., Perkin Trans. 2 1999, 765. (b) Lee, H. W.; Guha, A. K.; Lee, I. Int. J. Chem. Kinet. 2002, 34, 632. (c) Hoque, M. E. U.; Dey, S.; Guha, A. K.; Kim, C. K.; Lee, B. S.; Lee, H. W. J. Org. Chem. 2007, 72, 5493. (d) Hoque, M. E. U.; Lee, H. W. Btll. Korean Chem. Soc. 2007, 28, 936. (e) Hoque, M. E. U.; Dey, N. K.; Kim, C. K.; Lee, B. S.; Lee, H. W. Org. Bionol. Chem. 2007, DOI: 10.1039/B713167D, Pyridinolysis: (f) Guha, A. K.; Lee, H. W.; Lee, I. J. Org. Chem. 2000, 65, 12. (g) Lee, H. W.; Guha, A. K.;
Kim, C. K.; Lee, I. J. Org. Chem, 2002, 67, 2215. (h) Adhikary, K. K.; Lee, H. W.; Lee, I. Bull. Korean Chent. Soc. 2003, 24, 1135 . (i) Hoque, M. E. U.; Dey, N. K.; Guha, A. K.; Kim, C. K.; Lee, B. S.; Lee, H. W. Butl. Korean Chent. Soc. 2007, 28, 1797. Theoretical: (j) Lee, I.; Kim, C. K.; Li, H. G.; Sohn, C. K.; Kim, C. K.; Lee, H. W.; Lee, B. S. J. Am. Chem. Soc. 2000, $112,11162$.

5. Hehre, W. J.; Random, L.; Schleyer, P. V. R.; Pople, J. A. Ab Initio Molecttar Orbifal Theon; Wiley: New York, 1986; Chapter 4.

6. (a) Neimysheva, A. A.; Savchik, V.; Ermolaeva, M. V.; Knunyants, I. L. Bull. Acad. Sci. USSR Div. Chem. Sci. (Engl Transl) 1968, 2104. (b) Ketelaar, J. A. A.; Gresmann, H. R; Koopmans, K. Recl. Trav. Chim. Pays-Bas. 1952, 71, 1253. (c) Chlebowski, J. F.; Coleman, J. E. J. Biol. Chem. 1974, 247, 7192.

7. (a) Cook, R. D.; Farah, S.; Ghawi, L.; Itani, A.; Rahil, J. Can. J. Chem. 1986, 64, 1630. (b) Bel'skii, V. E.; Bezzubova, N. N.; Akamsin, V. D.; Eliseenkov, V, N.; Rizpolozhenskii, N. I.; Puduvik, A. N. Dokl. Akad. Nauk. SSSR 1971, 197, 85; Eng Trans PP. 171, (c) Onyido, I.; Swierczek, K.; Purcell, J.; Hengge, A. C. J. Am. Chem. Soc. 2005, 127, 7703. (d) Douglas, K. T.; Williams, A. J. Chem. Soc. Perkin Trans. 2 1976, 515. (e) Um, I. H.; Akhtar, K.; Shin, Y. H.; Han, J. Y. J. Org. Chent. 2007, 72, 3823. (I) Cook, R. D.; Daouk, W. A.; Hajj, Kabbani, A.; A. N.; Kurku, A.; Samaha, M.; Shayban, F.; Tanielian, O. V. Can. J. Chem. 1986, 64, 213 .

8. (a) Hengge, A. C.; Onyido, I. Curr. Org. Chem. 2005, 9, 6I. (b) Omakor, J. E.; Onyido, J.; vanLoon, G W.; Buncel, E. J. Chen. Soc, Perkin Trans. 2 2001, 324. (c) Gregersen, B. A.; Lopez, X.; York, D. M. J. Am. Chem. Soc. 2003, 125, 7178. (d) Hondal, R. J.; Bruzik, K. S.; Zhao, Z.; Tsai, M. D. J. Am. Chem. Soc. 1997, 119, 5477 .

9. Charton, M. Prog. Phys. Org. Chem. 1987, 16, 287

10. Hansch, C.; Leo, A.; Taf, R. W. Chen. Rev. 1991, 9/, 165.

11. Streitwieser, A. Jr.; Heathcock, C. H. Introdtction to Organic Chenistry; 3rd ed.; Macmillan Publishing Co.: New York, 1989; p 693.

12. (a) Ritchie, C. D. In Solute-Solvent Interactions; Coetzee, J. F; Ritchie, C. D., Eds.; Marcel Dekker: New York, 1969; Ch. 4. (b) Coetzee, J. F. Prog. Phys. Org. Chen. 1967, 4, 54. (c) Spillane, W. J.; Hogan, G.; McGrath, P.; King, J.; Brack, C. J. Chent. Soc, Perkin Trans. 2 1996, 2099. (d) Oh, H. K.; Woo, S. Y.; Shin, C. H.; Park, Y. S.; Lee, I. J. Org. Chem, 1997, 62, 5780.

13. (a) Ba-Sail, S. A.; Waring, M. A.; Williams, A. J. Am. Chem. Soc. 1990, 112, 8115. (b) Bourne, N.; Chrystiuk, E.; Davis, A. M.; Williams, A.J. Am. Chem. Soc. 1988, 110,1890 . (c) Bourne, N.; Williams, A. J. Am. Chem. Soc. 1984, 106, 7591. (d) Omakor, J. E.; Onyido, I.; vanLoon, G. W.; Buncel, E. J. Chen. Soc, Perkin Trans, $22001,324$.

14. (a) Lee, I. Chem. Soc. Rev, 1990, 19, 317. (b) Lee, I, Adv. Phys. Org. Chem. 1992, 27, 57. (c) Lee, I,; Lee, H. W. Collect. Czech. Chen. Connutm. 1999, 64, 1529 .

15. (a) Lee, I.; Koh, H. J.; Lee, B. S.; Lee, H. W. J. Chen. Soc., Chen. Conmin 1991, 335. (b) Melander, L.; Saunders, Jr. W. H. Reaction Rates of Isotopic Molecules; Wiley: New York, 1981. (c) Kaldor, S. B.; Saunders, Jr. W. H. J. Chem. Phys. 1978, 68, 2509. (d) Swain, C. C.: Pegues, E. E. J. Am. Chem. Soc. 1958, $80,812$. (e) Kwart, H. Acc. Chent. Res. 1982, 15, 401. (f) Kwart, H.; Brechbid, M. W.; Acheson, R. M.; Ward, D. C.J. Am. Chem. Soc. 1982, 104,4671 .

16. (a) Onyido, I.; Albright, K.; Buncel, E. Org. Bionol. Chem. 2005 , 3, L468. (b) Buncel, E.; Albright, K.; Onyido, I, ibid, 2004, 2, 60 I.

17. 17. Um, I. H.; Jeon, S. E.; Baek, M. H.; Park, H. R. Chem. Contmin 2003, 3016.

18. 18. Lee, I; Lee, H. W.; Sohn, S. C.; Kim, C. H. Tetrahedron 1985. 41,2635 . 